\title{
Algılanan Çevresel Sorunların Çevre Okuryazarlık Düzeyine Göre Analizi
}

\author{
Analysis of The Percieved Environmental Problems \\ According to Environmental Literacy Levels
}

\author{
Pınar FETTAHLIOĞLU*
}

\begin{abstract}
Öz: Bu çalışmanın amacı fen bilgisi öğretmeni adaylarının çizdikleri resimler yardımı ile algıladıkları çevresel sorunları çevre okuryazarlık düzeyine göre analiz etmektir. Araştırmanın çalışma grubunu 20132014 Eğitim-Öğretim yılında Türkiye'deki bir devlet üniversitesi eğitim fakültesi matematik ve fen bilimleri eğitimi bölümü fen bilgisi öğretmenliği anabilim dalında öğrenim gören 1.,2.,3. ve 4. sınıf toplam 120 ögrretmen adayı oluşturmaktadır. Bu araştırmada karma araştırma yöntemlerinden yakınsayan paralel desen kullanılmıştır. Nitel veri toplama aracı olarak öğrencilerin çizdikleri resimler ve resimler hakkında açık uçlu soruların yer aldığı görüş anketi ile nicel veri toplama araçlarından Kaplowitz ve Levine (2005) tarafından geliştirilen; Teksöz, Şahin ve Ertepınar (2010) tarafından Türkçeye uyarlanan çevre okuryazarlık ölçeği kullanılmıştır. Öğretmen adaylarına çizdirilen resimler ile öğretmen adaylarının açık uçlu sorulara verdikleri yanıtlar içerik analizine tabi tutulmuştur. Resimlerde ve görüşlerde yer alan simgeler ve sözlü ifadeler kodlanarak kategorize edilmiştir. Çevre okuryazarlık ölçeğinden elde edilen bulgular ise betimsel analiz yöntemi ile analiz edilmiştir. Araştırma sonuçları öğretmen adaylarının en fazla su, hava ve görsel kirlilik üzerinde ilgili olduklarını gösterdi. Öğretmen adaylarının çevresel sorunlara yönelik algılarının çevre okuryazarlık düzeylerine göre değiştiği tespit edildi.
\end{abstract}

Anahtar Kelimeler: Çevre okuryazarı, öğretmen yetiştirme, çevre eğitimi

\begin{abstract}
The purpose of this study is to analyze environmental problems perceived by pre-service science teachers according to their environmental literacy levels. The research is held in 2013-2014, at State University, Faculty of Education Mathematics and Science Education Science Teaching Department, $1^{\text {st }}, 2^{\text {nd }}, 3^{\text {rd }}$ and $4^{\text {th }}$ year students -120 students in total. Convergent parallel design as a mixed method was used in this research. Drawing-writing test and environmental literacy scale were used to collect data. The data of the study were collected in accordance with qualitative research methods such as open-ended questions and pre-service science teachers' drawings and quantitative research methods such as environmental literacy questioners was developed by Kaplowitz \& Levine (2005) and translated into Turkish by Teksöz, Şahin \& Ertepınar (2010). Pictures drawn by pre-service science teachers and pre-service science teachers' responses to open-ended questions were analyzed using descriptive analysis. The icons in pictures and the submissions with oral statements were categorized by coded. The findings obtained from the Environmental literacy scale were analyzed by using descriptive analyze method. According to the pre-service science teachers who participate in this study, the most important environmental issues are water pollution, air pollution, noise pollution, detractions of the forests, waste problem, natural disasters, squatter house problem and visual pollution. At the end of this study it was found that pre-service science teachers' perspectives according to environmental problems have changed according to their environmental literacy levels.
\end{abstract}

Keywords: Environmental Literacy, Teacher Education, Envrionmental Education

\section{Giriş}

Sanayileşme ile birlikte ortaya çıkan ve her geçen gün etkisini daha fazla hissettiğimiz çevresel sorunlar doğadaki ekosistemi olumsuz yönde etkileyen en önemli öğelerin başında gelmektedir (IPPC, 2014; Hungerford ve Simmons, 2003). Konu ile ilgili olarak Orr (1992) yapmış olduğu

*Dr. Öğretim Üyesi, Çukurova Üniversitesi, Eğitim Fakültesi, Adana-Türkiye, https://orcid.org/0000-0002-8639-

7613, e-posta: pinardnz@gmail.com 
çalışmasında; günümüzde yayımlanan çevre ile ilgili raporlar incelendiğinde nüfus, iklim değişikliği, kaynak tükenmesi ve türlerin yok olması gibi konulara değinilmeyen hiçbir politik veya ekonomik raporun olmadığını iddia etmektedir. Bu raporlara göre doğa; şu anki olduğu hali ile ekolojik eşiklere yönelik işlerse, ileriki dönemlerde insanları şu anda desteklediği oranda destekleyemeyecektir. Bu durumun en temel nedeni hiç kuşkusuz insanların çevrelerini kendi çıkarları uğruna bilinçsiz olarak kullanmaları gösterilmektedir (Newell ve Dale, 2015; Smith, 1974; Yin, Mizokami ve Aikawa, 2015). Çünkü insanlar sanayileşme ile birlikte daha refah içinde yaşayabilmek için; doğal ekosistemleri yok etti, onları bozulmuş ve basitleştirilmiş olanlarla değiştirdi. Bitkileri ve hayvanları evcilleştirdi, insan isteklerini ve ihtiyaçlarını karşılamak için onları kullandı. Buna karşılık, bitki ve hayvanların ihtiyaçları için çok az dikkate alınmak suretiyle enerji akışı kesintiye uğradı. Sürekli artan besin talebini karşılamak için fosil yakıtlar kullanılmaya başlandı. Bu yakıtlardan kaynaklanan atıklar ise hava, toprak ve suyu kirletmeye başladı ve devam etmekte (Smith, 1974). İfade edilen bu durumlar ise şu anki karşı karşıya olduğumuz çevre sorunlarını ortaya çıkardı. Bu durumda çevre sorunlarının çözüme kavuşturulması için yapılması gereken en önemli şeylerden biri; insanlara çevre ile ilgili konularda bilgi sahibi olması, çevrenin işleyişini anlayabilmesi ve çevreyi ona göre kullanması ve koruması gerektiği bilinci verilmelidir (Rickinson, 2001 ).

Çevreye karşı duyarlı bireyler yetiştirmenin en etkili faktörlerinden biri çevre eğitimidir (Erten, 2003; Rickinson, 2001; Sauve, 1996). Bu kapsamda Erten (2005) çevre eğitiminin amacını "bireylerin hem çevreyle ilgili bilgileri almasını sağlamak hem de bireylerde çevreye yönelik tutumlarının gelişmesini ve bu tutumların da davranışa dönüşmesini sağlamaktır." şeklinde ifade etmiştir. Çevre eğitimi, kapsadığ 1 amaç bakımından bütün derslerle ilişkili olduğundan çoğu ders (sosyal bilgiler, hayat bilgisi, fen bilimleri dersi) içinde yer almaktadır. İlk ve ortaokul kademesinde fen bilimleri dersi içinde de yer alan çevre eğitiminin hedefi, en temel şekli ile bütün bireylerin çevre okuryazarı olarak yetişmelerini sağlamaktır (Coyle, 2005; Culen, 1998; Dinsinger ve Roth, 1998; Knapp ve Barrie, 2001; Simmons, 2005; Stapp, 1969; Volk ve McBeth, 1997 ).

Çevre okuryazarlığ 1 ilk olarak 1968 yılında Roth tarafindan ortaya atılan bir kavram olup Türkiye'de 2008 yılında literatürde kullanılmaya başlanmıştır. Diğer ülkelerde de özellikle üzerinde durulan bu becerinin 1968 yılından bu yana çok fazla tanımı yapılmış olmasına karşın en çok kabul gören tanım Roth (1992) tarafından yapılan tanımdır. Roth'a (1992) göre çevre okuryazarlığı; bireyin çevre ile ilgili bilgilerini davranış olarak gösterebilme kapasitesidir. $\mathrm{Bu}$ tanımla birlikte Dinsinger ve Roth (1992); çevre okuryazarı bir birey hem geniş bir çevre bilgisine sahip olmalı hem de çevreye yönelik problemlerin fark edilmesi ve önlenmesi için çevreye yönelik inanç, görüş ve davranış becerilerini kullanabilmelidir. Bu ifadelerden yola çıkarak çevre okuryazarı bir bireyin doğa ve doğa olaylarına yönelik eleştirel düşünceler üretebilen, bu doğrultuda araştırma ve sorgulama yapabilen bir birey olduğu söylenebilir. Bu bağlamda çevre okuryazarlığı, bireyde doğa bilincinin oluşmasını sağlamakta, bireyin doğanın kanunlarını öğrenmesine ve bu doğrultuda doğayla iletişim kurmasına rehberlik etmektedir. Ayrıca birey bu şekilde çevre sorunlarına karşı duyarlı olmakta ve çözümler aramaktadır (Roth, 1992).

Çevre okuryazarlığının kapsadığı boyutlar ve alt boyutlar temel alınarak bu boyut ve alt boyutlara sahip olma durumuna göre Roth (1992) bireyleri üç düzeye ayırmıştır. Roth (1992) ve Disinger ve Roth'a (1992) göre bu üç düzeyin isimleri ve her bir düzeydeki bireyin genel özellikleri şöyledir:

Sözde çevre okuryazarlığı: $\mathrm{Bu}$ düzey çevre okuryazarlığının ilk düzeyi olarak isimlendirilmektedir. Bu düzeyde bireyler çevre ile ilgili konularda iletişim halindeyken çevre ile ilgili karmaşık olan kavramları kullanabilir ya da kullanılan kavramları anlayabilir. Çevre ile ilgili bir takım kavramları bilir ve bunların rahatlıkla tanımlarını temel şekilde yapabilir. Birey bu düzeyde çevreye ve çevre ile ilgili olaylara karşı tutum ve farkındalık da geliştirebilir. Ancak bu dönemde henüz birey insan ve doğa arasındaki ilişkiyi anlayacak alt yapıya sahip değildir. 
Ișlevsel çevre okuryazarlığl: İșlevsel çevre okuryazarlığı, okuryazarlığın ikinci düzeyidir. Bu düzeyde bireyler artık doğa ile insanlar arasındaki etkileşim hakkında geniş bir bilgi sahibi olmuştur. Birey çevre ile ilgili sorunlara karşı daha duyarlıdır. Bu kişiler birincil ve ikincil kaynakları kullanarak negatif etkileşimler hakkında analiz, sentez ve değerlendirme becerilerini geliştirmişlerdir. Bu düzeyde birey hem ikincil kaynaklardan sorunlarla ilgili bilgi toplamaya başlar hem de belirlenen çevre problemi ile ilgili olarak elindeki verilere göre değerlendirmeler yapar. Değerlendirmeyi yaparken kişisel değerler ve etik davranışları da göz önünde bulundurur. Yapmış olduğu değerlendirmeleri, bulgularını ve görüşlerini başkalarına aktarırlar.

Eylemsel çevre okuryazarlı̆̆ı: Çevre okuryazarlığının en üst düzeyi eylemsel düzeyidir. Bu düzeyde ön planda olan öğeler çevreye yönelik sorumlu davranışlardır. Bu düzeyde birey artık çevre ile ilgili konularda derin bilgiye sahiptir ve bu bilgiyi sürekli güncellemektedir. $\mathrm{Bu}$ düzeyde fark edilen durum, bireyin edindiği bilgileri çevrenin sürdürülebilirliğini sağlayan çevreye yönelik sorumlu davranışlara dönüştürülebilmesidir. Çevre ile ilgili olaylarla ilgili sorumlu davranış sergileyen bu bireyler aynı zamanda yaptıkları eylemlerin etkilerinin ve sonuçlarını düzenli olarak değerlendirirler. Bu konu ile ilgili gerekli bilgiyi toplarlar ve sentez yaparlar. Alternatif eylemler arasından doğruyu seçerler. Bu düzeydeki bir birey için çevre okuryazarlığı bir yaşam tarzıdır. Bu amaçla kişisel ve toplum olarak çevredeki doğal dengenin bozulmasını önlemek için güçlü bir sorumluluğa sahiptir. Bu bozulmayı engellemek için yerelden küresele kadar birçok düzeyde eyleme geçebilir.

Sayılan çevre okuryazarlık düzeyleri arasında bireylerin en üst basamağa ulaşabilmeleri için eğitim sisteminde en önemli öğelerden birinin fen bilgisi öğretmenleri olduğunu söylemek yanlış olmayacaktır. Çünkü öğretmenler öğrenme aktivitelerine ve öğrenme çevresine, bilgiye ulaşma yollarına, öğrencilerin çevre konularındaki gelişim düzeylerine karar verme gibi birçok düzenlemenin öncüsü konumundadır (Bağc1 Kılıç, 2003; Ernst, 2009; Liu, Yeh, Liang, Fang, Tsai, 2015; Plevyak ve diğerleri, 2001; Robottom ve Kyburz-Graber, 2000; Sözer, 1991). Bu bağlamda yapılandırmacı sistem anlayıșına göre derste bir rehber kişi olarak görev yapan öğretmen konular ve kazanımlar bazında yeterli bilgi ve beceriye sahip değilse, öğrencilere çok verimli olamaz, onları doğru şekilde yönlendiremez. Dolayısıyla etkili bir çevre eğitimi için fen bilgisi öğretmenlerinin de çevre okuryazarlık becerisini iyi bilmesi gerekmektedir.

Fen bilgisi öğretmenlerinin çevre eğitimi ile ilgili bilgi ve beceri edindikleri en önemli kurumlardan biri hizmet öncesi eğitimin verildiği eğitim fakülteleridir (Farsakoğlu, Şahin, Karsl1, Akpınar ve Ultay, 2008). Dolayısıyla eğitim fakültelerindeki öğretmen adaylarına çevre okuryazarlığı hakkında gerekli bilginin verilmesi, ilgili becerilerin kazandırılması için çevresel sorunlara yönelik bakış açılarının belirlenmesi ve elde edilen sonuçlara yönelik gerekli uygulamaların yapılması uygun yöntem ve tekniklerin kullanılması büyük önem taşımaktadır.

Çevre okuryazarlık düzeyi ve çevre sorunlarına yönelik bakış açısı üzerine yapılan çalışmalar incelendiğinde bu alanda yapılan çokça çalışmaya rastlamak mümkündür (Cheng ve Wu, 2015; Dillon ve Gayford, 1997; Liu, Yeh, Liang, Fang ve Tsai, 2015). Ancak ilgili literatür incelendiğinde fen bilgisi öğretmen adaylarının algıladıkları çevresel sorunların çevre okuryazarlık düzeyine göre analizini gerçekleştiren bir çalışmaya rastlanmamıştır. Oysaki nitelikli bir fen öğretmeninin, eğitim öğretim ortamında etkin olabilmesi ve hedeflenen becerileri öğrencilerin kazanmalarında onlara rehber olabilmesi için öncelikle ilgili becerilere de sahip olması gereklidir. Artan çevresel sorunlara karşı bilinçli bireylerin yetişmesi için çevre okuryazarlık becerisinin de gelişiminin önemi dikkate alındığında, eğitim fakültelerinde fen öğretmenlerinin çevre okuryazarlık becerilerinin de gelişimine önem verilmesi ve bu becerilere yönelik çevre sorunlarına karşı bakış açılarının analiz edilmesi gerekliliği ortaya çıkmaktadır. Dolayısıyla bu araştırmanın amacı; fen bilgisi öğretmeni adaylarının algıladıkları sosyal ve çevresel sorunları sınıf ve çevre okuryazarlık düzeyine göre analiz etmektir. Bu amaç kapsamında aşağıdaki sorulara yanıt aranmıştır:

- Fen bilgisi öğretmeni adaylarının çevre okuryazarlık düzeyleri nasıldır?

- Fen bilgisi öğretmeni adaylarının çevresel ve sosyal sorunlara yönelik algıları nasıldır? 
- Fen bilgisi öğretmeni adaylarının çevresel ve sosyal sorunlara yönelik algıları çevre okuryazarlık düzeylerine (alt, orta ve üst) göre göre nasıl bir dağılım göstermektedir?

\section{Yöntem}

$\mathrm{Bu}$ araştırma, nicel ve nitel araştırma yöntemleri birlikte kullanıldığı karma araştırma desenlerinden yakınsayan paralel desene göre tasarlanmıştır. Yakınsayan paralel desende iki veri kümesi (nicel ve nitel) ayrı ayrı ama eş zamanlı toplanır ve ayrı olarak analiz edilir. Son aşamada veriler birbirleri ile karşılaştırılır ya da ilişkilendirilir (Cresswell, 2012). Bu çalışmada da nicel ve nitel veriler birlikte aynı anda toplanmış ve birbirinden ayrı şekilde analiz edilmiştir. Ardından iki veri kümesinin birbiri ile ilişkisi incelenmiş ve sonuçlar yorumlanmıştır. Araştırmada, nicel araştırma desenlerinden tarama modeli kullanılmıştır. Bu aşamada fen bilgisi öğretmen adaylarının çevre okuryazarlık düzeyleri belirlenmiştir. İkinci aşamada ise nitel araştırma desenlerinden açıklayıcı durum çalışması deseni kullanılmıştır. Bu aşamada fen bilgisi öğretmen adaylarının çevre okuryazarlık düzeylerine göre çevresel sorunlara yönelik algıları incelenmiştir (Cresswell, 2012; Karasar, 1999; Yıldırım ve Şimşek, 2008). Çalışmanın sonunda ise katılımcıların çevre okuryazarlık düzeylerine göre çevre sorunlarını algılama durumları incelenmiştir.

Kullanılan karma araştırma deseninde nicel ve nitel bölümlerin hangi araştırma sorularını yanıtlamak için kullanıldığı, ilgili sorulara yönelik kullanılan örneklem ve veri toplama araçları Tablo 1'de sunulmuştur.

Tablo 1.

Karma Araştırma Deseninde Araştırma Sorularına Göre Kullanılan Yöntemler, Örneklem ve Veri Toplama Araçları

\begin{tabular}{|c|c|c|c|}
\hline Araştırma soruları & $\begin{array}{l}\text { Kullanılan } \\
\text { yöntem }\end{array}$ & $\begin{array}{r}\text { Örneklem } \\
\text { büyüklüğü }\end{array}$ & $\begin{array}{l}\text { Veri toplama } \\
\text { araçları }\end{array}$ \\
\hline $\begin{array}{l}\text { Fen bilgisi öğretmeni adaylarının çevre } \\
\text { okuryazarlık düzeyleri nasıldır? }\end{array}$ & $\begin{array}{l}\text { Betimsel } \\
\text { tarama }\end{array}$ & 120 & $\begin{array}{l}\text { Çevre } \\
\text { okuryazarlık } \\
\text { ölçeği }\end{array}$ \\
\hline $\begin{array}{l}\text { Fen bilgisi öğretmeni adaylarının çevresel ve sosyal } \\
\text { sorunlara yönelik algıları nasıldır? }\end{array}$ & $\begin{array}{l}\text { Açıklayı1c1 } \\
\text { durum } \\
\text { çalışması }\end{array}$ & 120 & $\begin{array}{l}\text { Öğrenci } \\
\text { çizimleri }\end{array}$ \\
\hline $\begin{array}{l}\text { Fen bilgisi öğretmeni adaylarının çevresel ve sosyal } \\
\text { sorunlara yönelik algıları çevre okuryazarlık } \\
\text { düzeylerine (alt, orta ve üst) göre göre nasıl bir } \\
\text { dağılım göstermektedir? }\end{array}$ & $\begin{array}{l}\text { Açıklayıc1 } \\
\text { durum } \\
\text { çalışması }\end{array}$ & 120 & $\begin{array}{l}\text { Öğrenci } \\
\text { çizimleri ve } \\
\text { çevre } \\
\text { okuryazarlık } \\
\text { ölçeği }\end{array}$ \\
\hline
\end{tabular}

\section{Çalışma grubu}

$\mathrm{Bu}$ araştırma uygun örnekleme yöntem ile belirlenen, 2013-2014 yılı bahar yarıyılında bir devlet üniversitesinde Eğitim Fakültesi Matematik ve Fen Bilimleri Eğitimi Bölümü Fen Bilgisi Öğretmenliği Anabilim dalında 33(\%27.5) 1.sınıf, 40 (\%33.3) 2.sınıf, 26 (\%21.6) 3.sınıf ve 21 (\%17.5) 4. Sinıfta öğrenim gören toplam 120 öğretmen adayı ile gerçekleştirilmiştir. Katılımcıların belirlenmesi sürecinde yaşanacak olası problemleri (Knight ve ark., 2013) en aza indirebilmek için, araştırmada öncelikle araştırmacıların gönüllü olma şartı ikinci ise araştırmacının kolay ulaşılabilirliği şartı dikkate alınmıştır.

\section{Veri toplama araçları}

Araştırma verilerinin toplanması için Kaplowitz ve Levine (2005) tarafından geliştirilen; Teksöz, Şahin ve Ertepınar (2010) tarafından Türkçeye uyarlanan çevre okuryazarlık ölçeği ile çizme yazma tekniği kullanılmıştır. 
Çevre Okuryazarlık Ölçeği: Kaplowitz ve Levine (2005) tarafından geliștirilen; Teksöz, Șahin ve Ertepınar (2010) tarafından Türkçeye uyarlanan çevre okuryazarlık ölçeği kullanılmıştır. ÇOYÖ (çevre okuryazarlık ölçeği) üniversite öğrencilerinin çevre okuryazarlığını, bilgi, tutum, kullanım ve ilgi başlıkları olmak üzere 4 kategori altında incelemektedir. Ölçeğin çevre bilgisi kategorisi 11 adet çoktan seçmeli sorudan oluşmaktadır. Bu kısımda yer alan soruların konusu ağırlıklı olarak güncel çevre konuları üzerinedir. Ayrıca bu bölümde yer alan her madde için "bilmiyorum" seçeneği bulunmaktadır. Çalışma kapsamında bilgi sorularına verilen için her doğru yanıt için " 1 " puan; yanlış yanıt ve bilmiyorum seçeneği için ise "0" puan verilmiştir. Çevre okuryazarlık ölçeğinin 2. kategorisi çevreye yönelik tutum olarak belirlenmiştir. Bu kategori 5'li likert tipinde hazırlanan toplam 9 maddeden oluşmaktadır. Tutum boyutunda yer alan maddelerden 19., 21 ve 22. maddeler olumsuz maddelerdir. 3. kategori çevre ile ilgili kullanımlar olarak isimlendirilmiştir. 5'li likert tipinde hazırlanan kategori 19 maddeden oluşmaktadır. Ölçekte yer alan tüm likert tipi bulunan maddeler için "kesinlikle katılıyorum" için 5, "katıllyorum" için 4, "kararsızım" için 3, "katılmıyorum" için 2, "kesinlikle katılmıyorum" için 1 puan verilmiştir. Olumsuz maddeler için ise tam tersi puanlama yapılmıştır. Son kategori çevre sorunlarına ilgi olarak tanımlanmış olup 9 maddeden oluşmaktadır. Yine 5'li likert formatında olan bu kategorideki maddeler için , "çok ilgileniyorum"; 5, "ilgileniyorum"; 4, "biraz ilgileniyorum"; 3, "ilgilenmiyorum"; 2, "hiç ilgilenmiyorum"; 1 puan şeklinde kodlanmıştır. Ölçeğin güvenirlik değerleri Çevre ile ilgili kullanımlar boyutunda Cronbach alfa değeri; 0.81, Çevre sorunlarına ilgi boyutunda 0.88 Çevre bilgisi boyutunda 0.88 Çevreye yönelik tutum ise 0.70'dir (Teksöz, Şahin ve Ertepınar, 2010) . Ölçeğin bu çalışma için güvenirlik değeri hesaplandığında Çevreye ile ilgili kullanımlar boyutunda Cronbach alfa değeri; 0.80, Çevre sorunlarına ilgi boyutunda 0.85 Çevre bilgisi boyutunda 0.84 Çevreye yönelik tutum boyutunda ise 0.72 olarak tespit edilmiştir. Ölçeğin uygulama süresi 40 dakikadır.

Çizme Yazma Tekniği: Çizme yazma tekniği genel olarak el ürünleri olarak nitelendirilen çizimler ve çizimler ile ilgili ifadeleri içeren (Whitehead ve Mcniff, 2004) veri toplama tekniği şeklinde tanımlanabilir. İnsan zihninde gizli kalmış düşünceleri, anlamları, duyuşsal durumları ortaya çıkarmada ya da bilişsel yapı ile ilgili bilgi edinmede çokça kullanılan çizme yazma tekniği özellikle bu tür durumlarda zihinde oluşan görsel imajı ortaya çıkardığından güçlü veriler elde etmede çok yardımcı bir araç olarak kabul edilmektedir (Borthwick, 2011; Kurt, Gökmen ve Ekici, 2013). Çizme yazma tekniği bağlamında bu çalışmada katılımcılardan çevre sorunları ile ilgili resim çizmeleri istenmiştir. Ayrıca katılımcılardan çizdikleri resimde neyi resmetmek istediklerini açıklamaları da istenmiştir. Bu uygulamada katılımcılara resim çizimi için 5 dakika; resimde anlatmak istedikleri sorunları yazmaları için ise 5 dakika verilmiştir. Şekil 1'de çizme-yazma tekniğine ilişkin örnekler sunulmuştur.

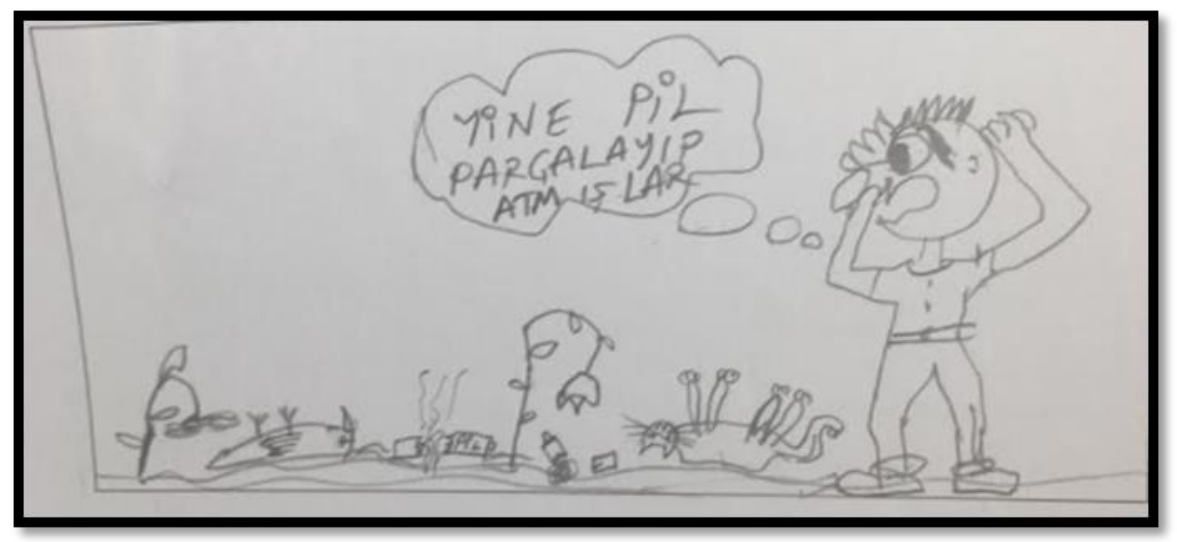

Şekil 1. K57’ye Ait Örnek Cevap Kâğıdı 


\section{Verilerin analizi}

Araştırmada nicel veri toplama aracı olarak; çevre okuryazarlık ölçeği kullanılmıştır. İfade edilen ölçek öğretmen adaylarının araştırma kapsamında ele alınan çevre okuryazarlık boyutlarındaki genel durumun tespiti üzerine kullanılmıştır. Bu bağlamda istatistiksel çözümlemeler SPSS 20.0 paket programı kullanılarak yapılmıştır. Ölçeğin bilgi boyutu için Kaplowitz ve Levine (2005) ve NEETF (2002) tarafından hazırlanan çevreye yönelik bilgi sınıflandırma rubriği kullanılmıştır. Bu rubriğe göre fen bilgisi öğretmeni adayları A, B, C, D, E ve $\mathrm{F}$ olmak üzere 5 kategoride sinıflandırılmaktadır. Bu kategoriler için doğru yanıta 1 puan diğer yanıtlara 0 puan verilir. Elde edilen toplam puan adayların çevre bilgisi seviyesini gösterir. İfade edilen kategoriler Tablo 2'de sunulmuştur.

Tablo 2.

Öğretmen Adaylarının Çevreye Yönelik Bilgi Düzeylerinin Sınıflandırması

\begin{tabular}{lllll}
\hline Doğru yanıt & Puan yüzdesi & Yanıtların yüzdesi & Sınıflandırma & Yeterlik durumu \\
& & & & \\
\hline 10 ve daha fazla & $90 \%-100 \%$ & 23.1 & A & Yeterli \\
9 & $80 \%-89 \%$ & 29.4 & B & Yeterli \\
8 & $70 \%-79 \%$ & 24.4 & C & Yeterli \\
7 & $60 \%-69 \%$ & 14.5 & D & Yetersiz \\
\hline
\end{tabular}

Diğer boyutların analizi için ise aritmetik ortalama, standart sapma, frekans, yüzde kullanılmıştır. Nitel verilerin analizinde betimsel analiz yöntemi kullanılmıştır. Bu analiz için Köse (2008); Kurt, Gökmen ve Ekici (2004), Taştan Kırık ve Kaya (2014) ile Reiss ve Tunnicliffe (2001) tarafından hazırlanan kategoriler temel alınmıştır. Köse (2008) ile Reiss ve Tunnicliffe (2001)'e göre çizimlerin analizi için ifade edilen 5 ana ölçüt bağlamında seviyeler oluşturulmuş ve çizimler bu seviyelere göre analiz edilmiştir. İfade edilen seviyeler aşağıda açıklanmıştır:

Seviye 1: Çizimi olmayanlar: Çizim yok

Seviye 2: Temsili olmayan çizimler: Çevresel sorunlarla ilgili bir veya iki yapının gösterildiği veya temsili olmayan resim çizimler.

Seviye 3: Alternatif kavramaları içeren çizimler: içerisinde alternatif kavramaların bulunduğu çizimler.

Seviye 4: Kısmi çizimler: Çevresel sorunla ilgili en az dört sebebi ifade eden ama genel yapının eksik olduğu kısmen doğru çizimler.

Seviye 5: Kavramsal temsili çizimler: Tam anlamanın mevcut olduğu, en gerçekçi ve doğruya yakın çizimler.

Yukarıda açıklanan her seviyeye ait çizim örnekleri Tablo 3'de verilmiştir. 
Tablo 3.

Öğretmen Adaylarının Çizmiş Oldukları Resimlerin Kategorilere İlişsin Örnekleri

\begin{tabular}{ll}
\hline Seviyeler & Çizim örnekler \\
\hline Seviye 1 & Çizim yok \\
\hline Seviye 2 & K14'e Ait Resim \\
\hline Seviye 3 &
\end{tabular}

K7'ye Ait resim

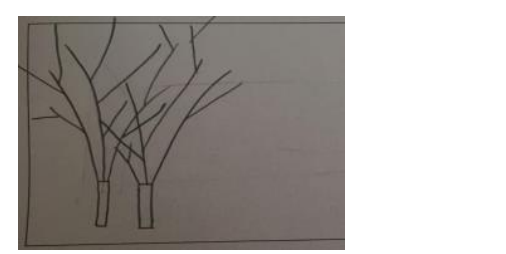

K8'e Ait Resim

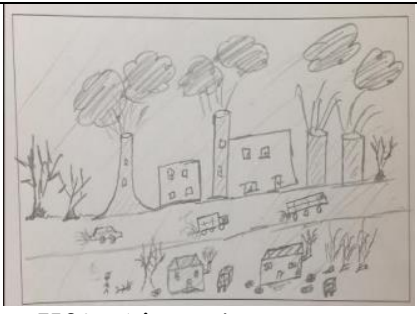

K3'e Ait Resim

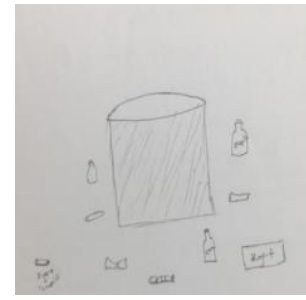

K38'e Ait Resim

Seviye 4

$$
\text { Çizim yok }
$$

Çizimlerden elde edilen sonuçlar yüzde frekans tablosu halinde sunulmuștur. Nitel verilerin güvenirlik değerlerini hesaplamak için Miles ve Huberman'ın (1994) uyuşum yüzdesi formülü dikkate alınmıştır: [Görüş birliği / (Görüş birliği + Görüş ayrılı̆̆ı) x 100]. İki ayrı araştırmacı tarafından çizimlerin ayrı zamanlarda bağımsız olarak kodlanması sonrasında tutarlılığa bakılmış ve ortalama güvenirlik \% 84 olarak bulunmuştur.

\section{Bulgular}

Fen bilgisi ögretmeni adaylarının çevreye yönelik okuryazarlık düzeyleri

Çevre okuryazarlık ölçeğinden elde edilen veriler her bir kategori için madde bazında analiz edilmiş olup sonuçlar yüzde frekans dağılımı şeklinde sunulmuştur. $\mathrm{Bu}$ nedenle çalışmanın bulguları çevre okuryazarlık ölçeğinin alt boyutları alt başlıklar şekilde düzenlenmiştir.

Çevre bilgisi: Öğretmen adaylarının çevreye yönelik bilgi sorularına verdikleri yanıtlara ilişkin yüzde frekans dağılımı Tablo 4'de sunulmuştur. 
Tablo 4.

Çevreye Yönelik Bilgi Sorularına Verilen Yanıtların Yüzde Frekansları

\begin{tabular}{|c|c|c|c|}
\hline $\begin{array}{l}\text { Madde } \\
\text { No }\end{array}$ & Madde & $f$ & $\%$ \\
\hline \multirow[t]{6}{*}{4} & \multicolumn{3}{|c|}{$\begin{array}{l}\text { Çok çeşitli bitki ve hayvan türleri vardır ve bunlar çok farklı } \\
\text { ortamlarda yaşamaktadır. Bu düşünceyi tanımlamak için kullanılan } \\
\text { sözcük hangisidir? }\end{array}$} \\
\hline & - Çeşitlilik & 11 & 9.2 \\
\hline & $\checkmark$ Biyolojik çeşitlilik & 10 & 84.2 \\
\hline & - Sosyo-ekonomik & 0 & 0 \\
\hline & - Evrim & 5 & 4.2 \\
\hline & - Bilmiyorum & 3 & 2.5 \\
\hline
\end{tabular}

Türkiye'de karbon monoksit hava kirliliği yaratan önemli bir

5 kirleticidir. Aşağıdakilerden hangisi en önemli karbon monoksit kaynağıdır?

\begin{tabular}{lll}
\hline - Fabrikalar ve işyerleri & 93 & 77.5 \\
- İnsanların nefes alıp vermesi & 4 & 3.3 \\
$\checkmark$ Motorlu araçlar & 21 & 17.5 \\
- Ağaçlar & 0 & 0 \\
- Bilmiyorum & 2 & 1.7 \\
\hline
\end{tabular}

Türkiye'de elektrik üretimi büyük ölçüde nasıl gerçekleştirilmektedir?

6

- Petrol, kömür ve odun yakılarak $\quad 14 \quad 11.7$

- Nükleer santrallar ile $\quad 19 \quad 15.8$

- Güneş enerjisi ile $\quad 6 \quad 5.0$

$\checkmark$ Hidro elektrik santraller ile $\quad 65 \quad 54.2$

- Bilmiyorum $16 \quad 13.3$

Türkiye'deki akarsu ve deniz kirliliğinin en temel nedeni nedir?

7 sular

- Bahçe ve caddelerden akan sular $\quad 1 \quad 8$

- Kumsal ve plajlardan atılan çöpler $\quad 2 \quad 1.7$

- Şehir çöplerinin boşaltılması $\quad 7 \quad 5.8$

- Bilmiyorum 00

\begin{tabular}{|c|c|c|c|}
\hline \multirow{6}{*}{8} & \multicolumn{3}{|c|}{ Aşağıdakilerden hangisi yenilenebilir bir kaynaktır? } \\
\hline & - $\quad$ Petrol & 7 & 5.8 \\
\hline & - Demir Madeni & 10 & 8.3 \\
\hline & $\checkmark$ Ağaçlar & 71 & 59.2 \\
\hline & - Kömür & 5 & 4.2 \\
\hline & - Bilmiyorum & 27 & 22.5 \\
\hline
\end{tabular}

Ozon, atmosferin üst katmanlarında koruyucu bir tabaka oluşturur. Ozon bizi aşağıdakilerden hangisinden korur?

\begin{tabular}{lllll} 
& $\bullet$ & Asit yağmurları & 10 & 8.3 \\
\hline 9 & $\bullet$ Küresel 1sınma & 27 & 22.5 \\
& $\bullet$ Sicaklıktaki ani değişimler & 6 & 5.0 \\
& $\checkmark$ Zararlı, kansere neden olan güneş 1şı̆̆ı & 71 & 59.2 \\
& $\bullet$ Bilmiyorum & 6 & 5.0 \\
\hline \multicolumn{5}{c}{ Türkiye'de çöplerin büyük bir kısmı nereye } \\
& atılır? & 15 & \\
\cline { 2 - 5 } 10 & $\bullet$ & Denizler & 12.5
\end{tabular}




\begin{tabular}{|c|c|c|c|}
\hline & \multirow{5}{*}{$\begin{array}{l}\text { - } \text { Yakma tesisleri } \\
\text { - Geri dönüşüm merkezleri } \\
\checkmark \text { Çöp depolama alanları } \\
\text { - } \text { Bilmiyorum }\end{array}$} & \multirow[b]{2}{*}{13} & \multirow[b]{2}{*}{108} \\
\hline & & & \\
\hline & & 12 & 10.0 \\
\hline & & 59 & 49.2 \\
\hline & & 21 & 17.5 \\
\hline \multirow[t]{6}{*}{11} & \multicolumn{3}{|l|}{$\begin{array}{l}\text { Türkiye'de çevreyi korumaya yönelik } \\
\text { kararlar alan resmi kurumun adı nedir? }\end{array}$} \\
\hline & $\checkmark$ Çevre ve Şehircilik Bakanlığ 1 & 64 & 53.3 \\
\hline & - TEMA & 33 & 27.5 \\
\hline & - Tabiatı Koruma Vakfi & 1 & 0.8 \\
\hline & - Türkiye Cevre Eğitim Vakfi & 6 & 5.0 \\
\hline & - Bilmiyorum & 16 & 13.3 \\
\hline \multirow[t]{6}{*}{12} & \multicolumn{3}{|l|}{$\begin{array}{l}\text { Aşağıdaki evsel atıklardan hangisi zararlı } \\
\text { atık olarak adlandırılabilir? }\end{array}$} \\
\hline & - Plastik ambalajlar & 27 & 22.5 \\
\hline & - Cam & 2 & 1.7 \\
\hline & $\checkmark$ Piller & 80 & 66.7 \\
\hline & - Yemek artıkları & 4 & 3.3 \\
\hline & - Bilmiyorum & 7 & 5.8 \\
\hline \multirow{6}{*}{13} & \multicolumn{3}{|l|}{$\begin{array}{l}\text { Hayvan türlerinin nesillerinin tükenmesinin } \\
\text { en yaygın sebebi nedir? }\end{array}$} \\
\hline & $\begin{array}{l}\text { - Pestisitler hayvanların ölmesine yol } \\
\text { açmaktadır. }\end{array}$ & 1 & 0.8 \\
\hline & $\begin{array}{l}\checkmark \text { Yaşam alanları insanlar tarafindan yok } \\
\text { edilmektedir. }\end{array}$ & 91 & 75.8 \\
\hline & - Avcılık çok artmıştır. & 11 & 9.2 \\
\hline & $\begin{array}{l}\text { - İklim değişiklikleri hayvanları } \\
\text { etkilemektedir. }\end{array}$ & 11 & 9.2 \\
\hline & - Bilmiyorum. & 6 & 5.0 \\
\hline \multirow[t]{6}{*}{14} & \multicolumn{3}{|l|}{$\begin{array}{l}\text { Bilim adamları nükleer atıkların } \\
\text { depolanması ile ilgili çalışmalarında } \\
\text { henüz sonuca ulaşamamışlardır. Şu anda } \\
\text { dünyada yaygı̀ olan nükleer atık } \\
\text { depolama yöntemi nedir? }\end{array}$} \\
\hline & - Nükleer yakıt olarak kullanılmaktadır & 15 & 12.5 \\
\hline & - Başka ülkelere satılmaktadır & 11 & 9.2 \\
\hline & $\begin{array}{l}\text { - Çöp depolama alanlarında depo } \\
\text { edilmektedir }\end{array}$ & 7 & 5.8 \\
\hline & $\begin{array}{l}\checkmark \text { Depolanmakta ve kontrol altında } \\
\text { tutulmaktadır }\end{array}$ & 29 & 24.2 \\
\hline & - Bilmiyorum & 58 & 48.3 \\
\hline
\end{tabular}

Tablo 4 incelendiğinde öğretmen adaylarının; en fazla Türkiye'deki akarsu ve deniz kirliliğinin en temel nedeni ile ilgili soruya doğru olarak cevapladıkları (\%91) tespit edilmiştir. $\mathrm{Bu}$ yanıtı daha sonra biyo çeşitlilik (\%84.2) ve türlerin azalması (\%75.8) ile ilgili sorular takip etmiştir. Diğer taraftan öğretmen adaylarının önemli karbon monoksit kaynağı olarak motorlu araçların yer aldığı soruya $(\% 17)$ ise en az doğru yanıt verdikleri belirlenmiştir. Ayrıca \%43'ünün nükleer atık depolama yöntemleri ile ilgili bilgilerinin olmadığı tespit edilmiştir. Öğretmen adaylarının bilgi boyutundan almış oldukları puanların genel dağglımı incelendiğinde ise ortalamanın 5.9 olduğu görülmektedir. Kaplovitz ve Levin'nin (2005) sinıflandırması dikkate alındığında bu seviyenin yetersiz olduğu görülmektedir. Başka bir deyişle öğretmen 
adayları çevre okuryazarlığının bilgi alt boyutunda düşük seviyede yer almaktadırlar

Öğretmen adaylarının bilgi düzeylerini tespit etmek için yüzde frekans analizi yapılmış ve sonuçlar Şekil 2'de sunulmuştur:

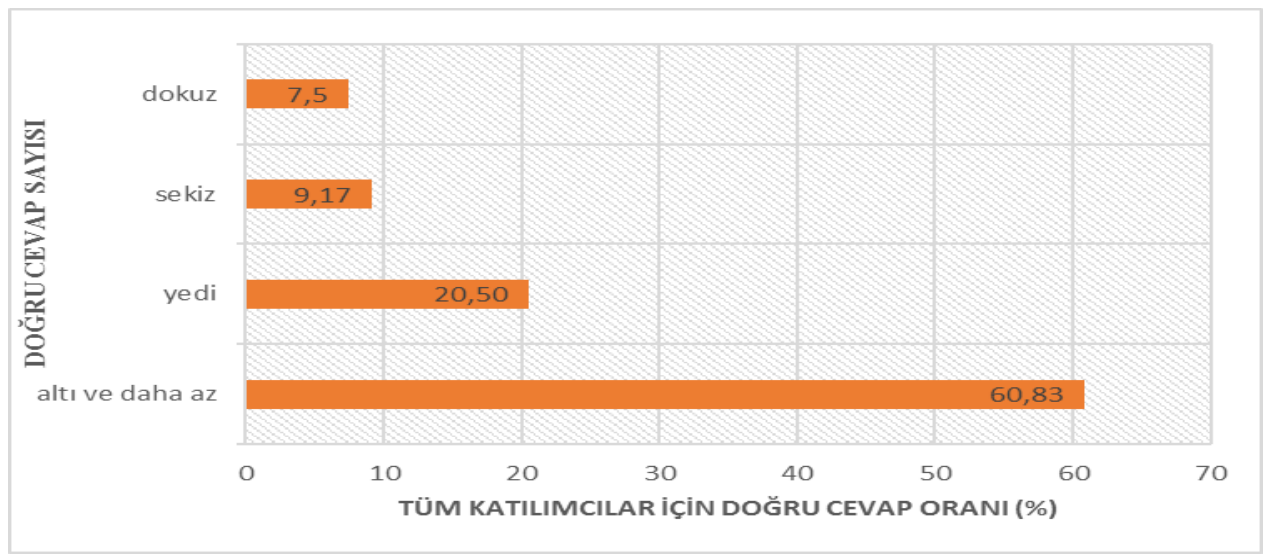

Şekil 2. Fen Bilgisi Öğretmen Adaylarının Çevreye Yönelik Bilgi Düzeyleri

Şekil 2'de görüldüğü üzere öğretmen adaylarının \%61'i 6 puan ve aşağısını alırken $\% 20$ 'si 7 puan; \%9'u 8 puan ve \%7'si ise 9 puan almışlardır. Kaplovitz ve Levin'in (2005) sınıflandırması dikkate alındığında öğretmen adaylarının \%61'inin bilgilerinin yeteriz olduğu \%39'unun ise yeterli bilgiye sahip olduğu söylenebilir.

Çevreye Yönelik Tutum: Öğretmen adaylarının tutum düzeylerini tespit etmek için her soruya verdikleri yanıtlara göre yüzde frekans analizi yapılmış ve sonuçlar Tablo 5'de sunulmuştur.

Tablo 5.

Çevreye Yönelik Tutum Maddelerine Verilen Yanıtların Yüzde Frekansları

\begin{tabular}{|c|c|c|c|c|c|c|c|}
\hline \multirow[t]{2}{*}{ 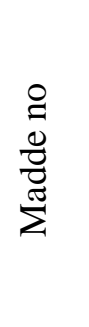 } & \multirow[t]{2}{*}{ Madde } & 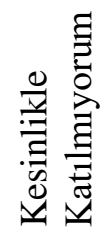 & 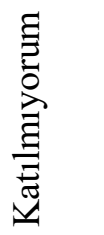 & 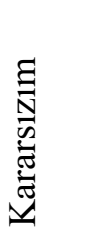 & 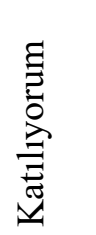 & 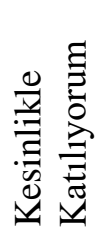 & \multirow[b]{2}{*}{$\hat{n}$} \\
\hline & & $\%$ & $\%$ & $\%$ & $\%$ & $\%$ & \\
\hline 15 & $\begin{array}{l}\text { Dünyanın insan yaşamın1 } \\
\text { destekleme kapasitesini } \\
\text { doldurmak üzereyiz. }\end{array}$ & 0 & 8.3 & 30 & 45.8 & 15.8 & $\begin{array}{ll}3.6 & .83\end{array}$ \\
\hline 16 & $\begin{array}{l}\text { İnsanların doğaya müdahale } \\
\text { etmesi genellikle felaketle } \\
\text { sonuçlanır. }\end{array}$ & 0.8 & 19.2 & 20.0 & 42.5 & 42.5 & $3.5 \quad 1.01$ \\
\hline 17 & $\begin{array}{l}\text { Dünyada herkese yetecek } \\
\text { miktarda doğal kaynak vardır. } \\
\text { sorun bu kaynaklardan nasıl } \\
\text { yararlanacağımızı̈ örenmektir. }\end{array}$ & 0.8 & 5.0 & 5.8 & 50.8 & 37.5 & $4.1 \quad .82$ \\
\hline 18 & $\begin{array}{l}\text { Bitki ve hayvanlar da insanlar } \\
\text { kadar var olma yaşama hakkına } \\
\text { sahiptir. }\end{array}$ & 0 & 0 & 2.5 & 10.8 & 86.7 & $\begin{array}{ll}4.8 \quad .42\end{array}$ \\
\hline $19 *$ & $\begin{array}{l}\text { Doğanın dengesi modern } \\
\text { endüstrileşmiş toplumların }\end{array}$ & 3.3 & 24.2 & 30.0 & 30.8 & 11.7 & $3.23 \quad 1.05$ \\
\hline
\end{tabular}




\begin{tabular}{|c|c|c|c|c|c|c|c|}
\hline & $\begin{array}{l}\text { etkileri ile rekabet edebilecek } \\
\text { güçtedir. }\end{array}$ & & & & & & \\
\hline 20 & $\begin{array}{l}\text { Bizi diğer canlılardan üstün } \\
\text { kılan özel yeteneklerimize } \\
\text { rağmen, hala doğa yasaları ile } \\
\text { mücadele ediyoruz. }\end{array}$ & 5.0 & 18.3 & 21.742 .5 & 12.5 & 4.0 & 1.07 \\
\hline $21^{*}$ & $\begin{array}{l}\text { İnsanların karşı karşıya } \\
\text { kaldıkları 'Ekolojik kriz' olarak } \\
\text { adlandırılan olaylar fazlasıyla } \\
\text { abartılmaktadır. }\end{array}$ & 1.7 & 6.7 & 16.749 .2 & 49.2 & 4 & .91 \\
\hline $22 *$ & $\begin{array}{l}\text { İnsan olmak doğanın geri kalan } \\
\text { bölümüne hükmetmektir. }\end{array}$ & 2.5 & 13.3 & $\begin{array}{ll}5.8 & 36.7\end{array}$ & 41.7 & 4 & 1.11 \\
\hline 23 & $\begin{array}{l}\text { İnsanlar doğayı kontrol } \\
\text { edebilmek için doğayı anlamak } \\
\text { gerektiğini sonunda } \\
\text { ögrrenecekler. }\end{array}$ & 2.5 & 1.7 & 10.851 .7 & 33.3 & 4 & .85 \\
\hline 24 & $\begin{array}{l}\text { Eğer her şey bugünkü gibi } \\
\text { devam ederse, yakında büyük } \\
\text { bir ekolojik facia ile } \\
\text { karş1laşacağız. }\end{array}$ & 2.5 & 2.5 & 4.240 .8 & 50.0 & 4.5 & .87 \\
\hline \multicolumn{2}{|c|}{ Ortalama } & 1.91 & 9.92 & 14.740 .1 & 38.0 & 4.01 & 0.89 \\
\hline
\end{tabular}

Tablo 5 incelendiğinde öğretmen adaylarının; en fazla bitki ve hayvanların insanlar kadar yaşama hakkı olduğunu ifade eden maddeye yüksek oranda katıldıkları (\%86.7) tespit edilmiştir. Bu durumu daha sonra insanların doğayı anlaması gerektiğini ifade eden madde (\%51.7) ve dünyadaki kaynakları bilinçli kullanmayı ifade eden madde (\%50.8) takip etmiştir. Diğer taraftan öğretmen adaylarının; doğanın dengesinin insanların sanayileşme çabaları ile mücadele edebileceği ile ilgili (\%30) maddesine karşı karasız yapıda olduklarını belirtmişlerdir. Elde edilen bu bulgular öğretmen adaylarının doğa ve doğanın öğelerine karşı eşit derecede olumlu tutum içinde bulunduklarını göstermekle birlikte doğanın kendini yenilebilme özelliği hakkında net bilgiye sahip olmadıklarını göstermektedir.

Çevre İle İlgili Kullanımlar: Öğretmen adaylarının çevre ile ilgili kullanım düzeylerini tespit etmek için her soruya verdikleri yanıtlara göre yüzde frekans analizi yapılmış ve sonuçlar Tablo 6' da sunulmuştur.

Tablo 6.

Çevre İle İlgili Kullanımlar Üzerine Örnek Maddeler İçin Frekans Dağılımları

\begin{tabular}{|c|c|c|c|c|c|c|c|c|}
\hline $\begin{array}{l}0 \\
z \\
i \\
i\end{array}$ & Maddeler & 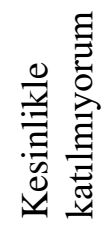 & 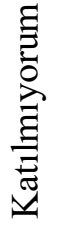 & 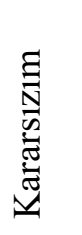 & 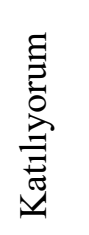 & 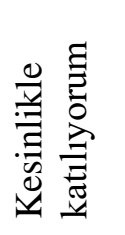 & \multirow[t]{2}{*}{$x$} & \multirow[b]{2}{*}{$\hat{s}$} \\
\hline & & $\%$ & $\%$ & $\%$ & $\%$ & $\%$ & & \\
\hline 26 & $\begin{array}{l}\text { Soyu tükenmekte olan } \\
\text { türler için özel alanlar } \\
\text { ayrılmalıdır. }\end{array}$ & 0.8 & 0.8 & 3.3 & 40.0 & 55.0 & 4.47 & .68 \\
\hline 27 & $\begin{array}{l}\text { Su kalitesi ile ilgili } \\
\text { yasalar daha yaptırımcı } \\
\text { olmalıdır. }\end{array}$ & 0.8 & 0 & 4.2 & 37.5 & 57.5 & 4.5 & .66 \\
\hline
\end{tabular}




\begin{tabular}{|c|c|c|c|c|c|c|c|}
\hline $28 *$ & $\begin{array}{l}\text { İnsanların et } \\
\text { ihtiyaçlarının } \\
\text { karş1landığı vahşi } \\
\text { hayvanlar korunması } \\
\text { gereken en önemli } \\
\text { türlerdir. }\end{array}$ & 7.5 & 33.3 & 43.313 .3 & 2.5 & 2.7 & .88 \\
\hline $29 *$ & $\begin{array}{l}\text { Zehirli y1lanlar ve } \\
\text { böcekler insanlar için } \\
\text { tehdit oluşturdukları için } \\
\text { öldürülmelidirler. }\end{array}$ & 5.0 & 3.3 & $7.5 \quad 35.8$ & 48.3 & 4.1 & 1.05 \\
\hline $30 *$ & $\begin{array}{l}\text { Toprak sahiplerine sulak } \\
\text { alanlarını tarımsal ve } \\
\text { endüstriyel amaçlar için } \\
\text { kullanmalarına izin } \\
\text { verilmelidir. }\end{array}$ & 18.3 & 41.7 & 25.811 .7 & 2.5 & 2.3 & .99 \\
\hline 31 & $\begin{array}{l}\text { Herkesin çevre } \\
\text { sorunlarının farkında } \\
\text { olması çok önemlidir. }\end{array}$ & 0.8 & 0.8 & $\begin{array}{ll}1.7 & 20.8\end{array}$ & 75.8 & 4.7 & .62 \\
\hline $32 *$ & $\begin{array}{l}\text { Şahıslar sahip oldukları } \\
\text { arazileri istedikleri } \\
\text { şekilde kullanmakta } \\
\text { serbest olmalıdır. }\end{array}$ & 4.2 & 6.7 & 13.360 .8 & 15.0 & 3.7 & .93 \\
\hline 33 & $\begin{array}{l}\text { Çevre sorunlarının } \\
\text { çözümlenmesinde kişisel } \\
\text { sorumluluklarım } \\
\text { olduğunu düşünüyorum. }\end{array}$ & 0 & 0.8 & $\begin{array}{ll}1.7 & 40.0\end{array}$ & 57.5 & 4.5 & .57 \\
\hline 34 & $\begin{array}{l}\text { Hükümet, vahşi } \\
\text { hayatın korunması } \\
\text { amacı ile özel } \\
\text { mülkiyet alanlarının } \\
\text { kullanımını } \\
\text { denetlemelidir. }\end{array}$ & 0.8 & 1.7 & $15.0 \quad 52.5$ & 30 & 4.09 & .76 \\
\hline 35 & $\begin{array}{l}\text { İnsanlar çevreye } \\
\text { verdikleri her türlü } \\
\text { zarardan sorumlu } \\
\text { tutulmalıdır. }\end{array}$ & 0 & 4.2 & 50.0 & 43.3 & 4.3 & .72 \\
\hline 36 & $\begin{array}{l}\text { Bitki ve hayvanların } \\
\text { tümü çevrede önemli bir } \\
\text { role sahiptir. }\end{array}$ & 0.8 & 0 & 20.8 & 76.7 & 4.7 & .57 \\
\hline 37 & $\begin{array}{l}\text { Teknolojik değişimlerin } \\
\text { çevre için yararları } \\
\text { olduğu kadar zararları da } \\
\text { vardır. }\end{array}$ & 0.8 & 0.8 & 48.3 & 46.7 & 4.3 & .67 \\
\hline 38 & $\begin{array}{l}\text { Hükümet geri dönüşümün } \\
\text { zorunlu olması yönünde } \\
\text { yasalar hazırlamalı ve } \\
\text { uygulamalıdır. }\end{array}$ & 0 & 0.8 & 39.2 & 56.7 & 4.5 & .60 \\
\hline $39 *$ & $\begin{array}{l}\text { Hava kirliliği ile ilgili } \\
\text { yasalar yeteri kadar } \\
\text { serttir. }\end{array}$ & 0.8 & 1.7 & $\begin{array}{ll}30.8 & 41.7\end{array}$ & 25 & 3.88 & .83 \\
\hline 40 & $\begin{array}{l}\text { Çevre problemlerinin } \\
\text { çözümünde bilim ve }\end{array}$ & 0.8 & 0 & $\begin{array}{ll}16.7 & 51.7\end{array}$ & 30.8 & 4.1 & .73 \\
\hline
\end{tabular}




\begin{tabular}{|c|c|c|c|c|c|c|c|c|}
\hline & $\begin{array}{l}\text { teknoloji çok } \\
\text { önemlidir. }\end{array}$ & & & & & & & \\
\hline 41 & $\begin{array}{l}\text { Çevre problemlerinin } \\
\text { çözümünde kültürel } \\
\text { farklılıklar çok } \\
\text { önemlidir. }\end{array}$ & 1.7 & 11.7 & 33.3 & 38.3 & 15.0 & 3.5 & .94 \\
\hline 42 & $\begin{array}{l}\text { İnsanların değer } \\
\text { yargılarının değişmesi } \\
\text { çevre problemlerinin } \\
\text { çözümlenmesinde rol } \\
\text { oynayacaktır. }\end{array}$ & 0 & 1.7 & 22.5 & 51.7 & 24.2 & 4.0 & .73 \\
\hline 43 & $\begin{array}{l}\text { Toplu eylemler çevre } \\
\text { problemlerinin } \\
\text { çözümünde önemli bir } \\
\text { yer tutar. }\end{array}$ & 2.5 & 15.8 & 31.7 & 38.3 & 11.7 & 4.05 & .64 \\
\hline 44 & $\begin{array}{l}\text { Yaşam } \\
\text { alışkanlıklarındaki } \\
\text { değişimler (tüketim gibi) } \\
\text { çevre problemlerinin } \\
\text { çözümlenmesinde önemli } \\
\text { rol oynayacaktır. }\end{array}$ & 0 & 2.5 & 10.8 & 65.8 & 20.8 & 4.01 & .33 \\
\hline \multicolumn{2}{|c|}{ Ortalama } & 2.4 & 6.7 & 14.3 & 39.9 & 36.5 & 4.02 & 0.73 \\
\hline
\end{tabular}

Tablo 6 incelendiğinde öğretmen adaylarının; en fazla bütün insanların çevre sorunlarının farkında olması gerektiğini $(\% 75)$ ve bütün canlıların çevrede önemli yerinin olduğunu (\%76) ifade eden maddelere olumlu görüş bildirdikleri tespit edilmiştir. Bu durumu daha sonra tüketim gibi alışkanların değişiminin çevresel sorunları önleyebileceği ile ilgili (\%65.8) maddesine verilen yanıtlar takip etmiştir. Öğretmen adaylarının insanların etinden yararlandıkları hayvanların öncelikli korunmaya ihtiyacı vardır şeklideki (\%43.3) maddesinde kararsız kaldıkları ve zehirli böceklerin insanların güvenliği için öldürülmeleri gerektiğine ilişkin (\%48.3) maddesine yüksek düzeyde olumlu yanıt verdikleri de görülmüştür.

Çevre Sorunlarına Yönelik İlgi: Öğretmen adaylarının ilgi düzeylerini tespit etmek için yüzde frekans analizi yapılmış ve sonuçlar Şekil 3'de sunulmuştur:

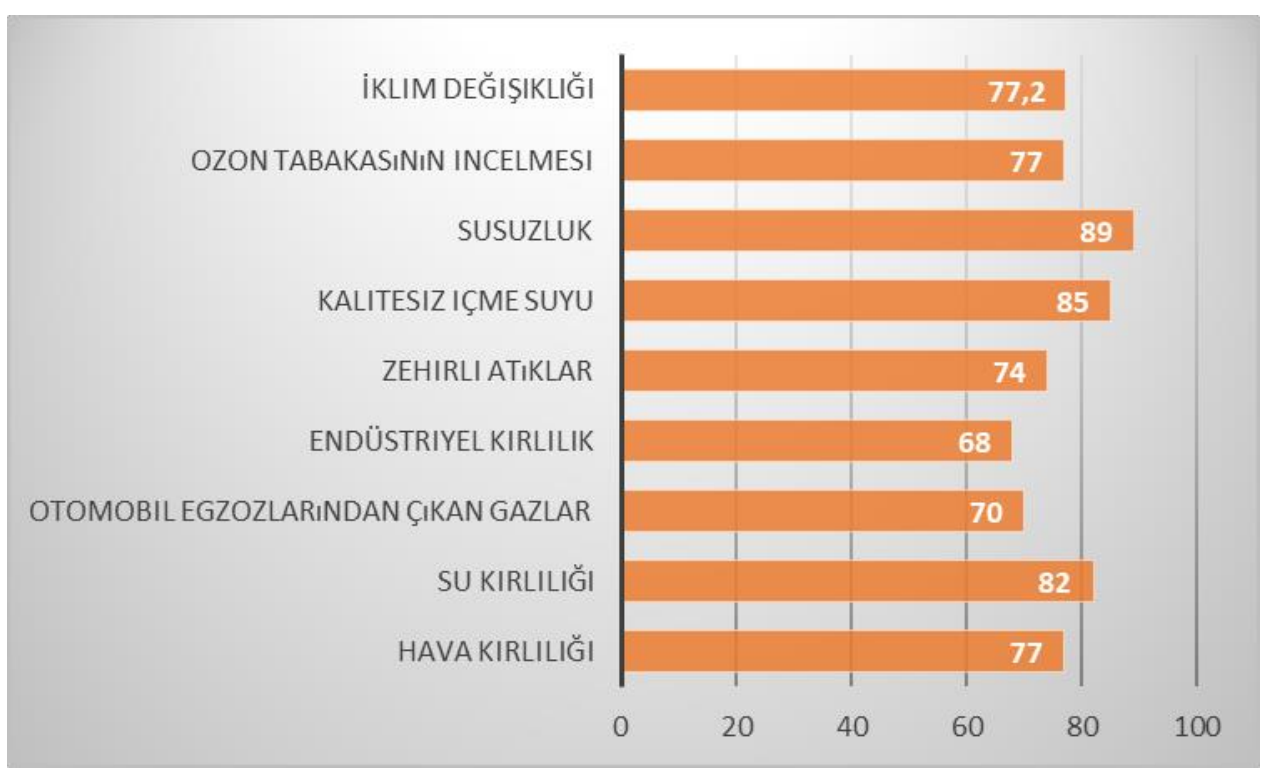

Şekil 3. Öğretmen Adaylarının Çevre Sorunlarına Yönelik İlgi Düzeyleri 
Şekil 3 incelendiğinde öğretmen adaylarının vermiş oldukları yanıtlarda en fazla susuzluk (\%89) kalitesiz içme suyu (\% 85), su kirliliği (\%82) ve hava kirliliği (\% 77) konularına yönelik ilginin olduğu tespit edilirken en az ilginin ise endüstriyel atıklar (\%68) ile ilgili konu üzerinde olduğu görülmüştür. İlgi duyulan çevre sorunları incelendiğinde bu sorunların öğretmen adaylarının yaşadıkları bölgede yer alan çevre sorunları olduğu görülmektedir.

Fen bilgisi öğretmeni adaylarının algıladıkları çevresel sorunlar: Bu bölümde öğretmen adaylarının çevre sorunları ve problemleri ile ilgili bilişsel yapılarına ait çizme-yazma tekniğiyle elde edilen bulgulara yer verilmektedir. Fen bilgisi öğretmeni adaylarının algıladıkları çevre sorunlarına ilişkin yüzde frekans analiz sonuçları Tablo 7'de sunulmuştur.

Tablo 7.

Fen Bilgisi Öğretmeni Adaylarının Çevre Sorunlarına Yönelik Algı Düzeylerinin Sınıf Düzeyine Göre Analizi

\begin{tabular}{|c|c|c|c|}
\hline \multicolumn{2}{|c|}{ Çevresel Problemler } & Çizim & Yazım \\
\hline \multirow{10}{*}{ 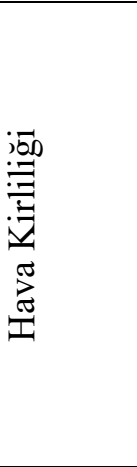 } & Fabrika dumanı & 20 & 9 \\
\hline & Soba dumanı (özellikle kömür) & 8 & 5 \\
\hline & Egzoz dumanı & 16 & 10 \\
\hline & Sigara dumanı & 6 & 5 \\
\hline & Çöp gazı & 2 & 3 \\
\hline & Bilinçsiz yakıt tüketimi & 0 & 1 \\
\hline & Parfüm ve deodorant & & \\
\hline & kullanımı & 3 & 2 \\
\hline & Ozon tabakasının incelmesi & 1 & 4 \\
\hline & Toplam & 54 & 39 \\
\hline \multirow{6}{*}{$\begin{array}{l}\text { Görsel } \\
\text { Kirlilik }\end{array}$} & Çöplerin yere atılması & 52 & 25 \\
\hline & Fabrika binaları & 10 & 0 \\
\hline & Plansız kentleşme & 5 & 2 \\
\hline & Sakızların yere atılması & 4 & 4 \\
\hline & $\begin{array}{l}\text { Alışveriş merkezlerinin } \\
\text { çoğalması }\end{array}$ & 1 & 1 \\
\hline & Toplam & 72 & 32 \\
\hline \multirow{6}{*}{ 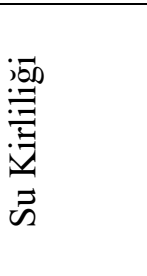 } & Fabrikaların sıvı atıkları & 12 & 6 \\
\hline & Evsel atıklar & 10 & 6 \\
\hline & Deniz kirliliği & 14 & 14 \\
\hline & Göllerin kuruması & 0 & 1 \\
\hline & Derelerin kurumas1 & 5 & 4 \\
\hline & Toplam & 41 & 31 \\
\hline \multirow{5}{*}{ 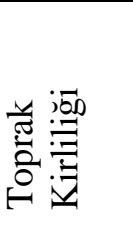 } & Atık piller & 6 & 4 \\
\hline & Evsel atıklar & 9 & 1 \\
\hline & Plastik atıklar & 7 & 2 \\
\hline & Geri dönüşümün önemi & 2 & 8 \\
\hline & Toplam & 25 & 14 \\
\hline \multirow{4}{*}{ 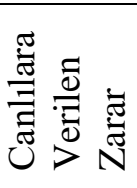 } & Türlerin yok olmas1 & 10 & 9 \\
\hline & İnsanların zarar görmesi & 2 & 1 \\
\hline & Balık ölümü & 6 & 1 \\
\hline & Çiçeklerin kuruması & 0 & 1 \\
\hline
\end{tabular}




\begin{tabular}{|c|c|c|c|}
\hline & Ağaçların kuruması & 5 & 3 \\
\hline & Ağaçların kesilmesi & 11 & 6 \\
\hline & Ormanların tahribatı & 1 & 2 \\
\hline & Kuşların ölümü & 2 & 2 \\
\hline & Toplam & 36 & 26 \\
\hline & Yağmurların yok olması & 1 & 1 \\
\hline$\Xi: \underline{a}$ & Suların azalması & 1 & 1 \\
\hline. & Küresel ısınma & 4 & 4 \\
\hline & Toplam & 7 & 7 \\
\hline Ses Kirliliŏ & Hoparlörden çıkan sesler & 1 & 1 \\
\hline Ses Kirnlligi & Toplam & 2 & 3 \\
\hline Biy. & Mikroplar & 1 & 2 \\
\hline Kirlilik & Toplam & 1 & 2 \\
\hline
\end{tabular}

Tablo 7'ye göre, öğretmen adaylarının çevre sorunlarına ilişkin çizim-yazım bulguları incelendiğinde en fazla görsel kirlilik, su kirliliği ve hava kirliliği konuları üzerinde çizimler ve açıklamalar yaptıkları tespit edilmiştir. Bu konular arasında en fazla egzoz dumanlarının etkisi, çöplerin yere atılması ve deniz kirliliği üzerindeki çizimlerin yoğunluk kazandığı belirlenmiştir. Diğer taraftan öğretmen adaylarının çizimlerinde en az yer verdikleri konuların ise iklim değişikliği, ses kirliliği ve biyo kirlilik konuları olduğu tespit edilmiştir. Bu bulgular öğretmen adaylarının çevre sorunlarına yönelik bilişsel yapılarını daha çok çevrelerinde yaşanan sorunlarla ilgili oluşturduğunu ifade etmektedir. Diğer taraftan tüm çizimler dikkate alınarak öğretmen adaylarının çevre sorunları durumu ile ilgili çizimlerine ait analizler ilgili seviyeler Şekil 4'de sunulmuştur.

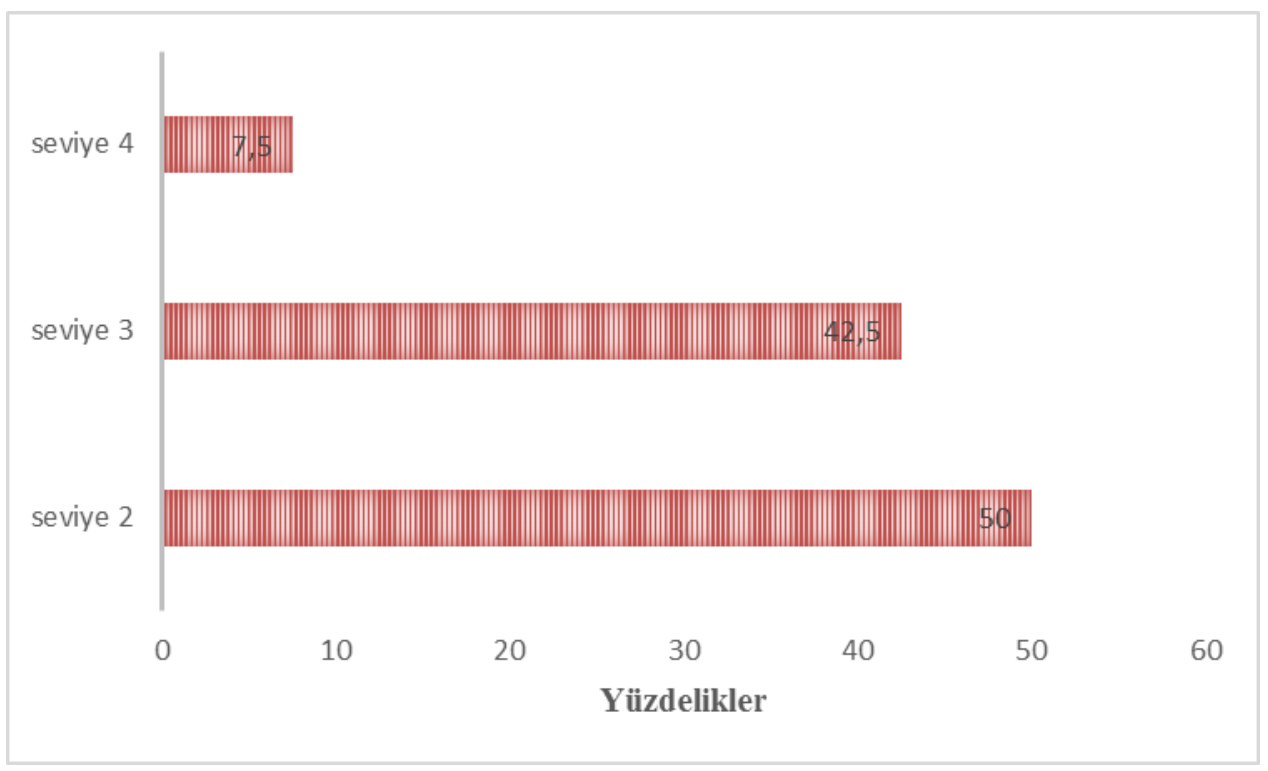

Şekil 4. Öğrenci çizimlerinin seviyelere göre dağılımı

Şekil 4'e göre, çevre sorunları ile ilgili ait öğretmen adaylarının çizimleri 5 seviye bağlamında analiz edilmiştir. Bu seviyelerin belirlenmesinde veriler seviye 1'den seviye 5'e kadar ayrılarak gruplandırılmıştır (Reiss ve Tunnicliffe, 2001). Seviye 1'de çizimi olmayan öğrenciler, seviye 2'de temsili olmayan çizimler, seviye 3'de: alternatif kavramaları içeren çizimler, seviye 4'de kısmi çizimler, seviye 5'de ise kavramsal temsili çizimler yer almaktadır. Elde edilen bulgularda seviye 1 ve seviye 5 'de yer alan katılımcilara rastlanmamıştır. Diğer 
taraftan katılımcıların çevre sorunlarına yönelik bilişsel yapılarını en fazla (\%50) temsili olmayan çizimlerle ifade ettikleri tespit edilmiştir. Ayrıca alternatif kavramları kullanarak bilişsel yapılarını ifade eden katılımcıların oranının $\% 42.5 \mathrm{k}$ ssmi çizimlerle ifade edenlerin ise \%7.5 olduğu belirlenmiştir. Bu bulgular öğretmen adaylarının çevre sorunlarına yönelik bilişsel yapılarını ağırlıklı olarak çevrelerinde gördükleri olaylar kapsamında ifade ettikleri, bilgilerini detaylandıramadıklarını vurgulamaktadır. Dolayısıyla bu çizimler çevre sorunları ile ilgili kavramsal yapılarının eksik olduğunu ortaya çıkarmaktadır.

Fen bilgisi ögretmeni adaylarının çevre okuryazarlık düzeyine göre çevre sorunlarına yönelik algl düzeyleri: Fen bilgisi öğretmeni adaylarının çevre okuryazarlık ölçeğinin genelinden aldığı puanların aritmetik ortalaması ve standart sapması dikkate alınarak öğretmen adayları alt, orta ve üst düzeye ayrılmıştır. Öğretmen adaylarının çevre okuryazarlık düzeylerine göre dağılımı Tablo 8'de verilmiştir.

Tablo 8.

Öğretmen Adaylarının Çevre Okuryazarlık Düzeylerine İlişkin Yüzde Frekans Dağıllımları

\begin{tabular}{ccccrr}
$\bar{x}$. & $\begin{array}{r}\text { Standart } \\
\text { Sapma }\end{array}$ & Başarı Aralığ 1 & Grup Ad 1 & Frekans & $\%$ \\
& & & & \\
\hline \multirow{3}{*}{4.44} & 0.55 & $0>\mathrm{X} \leq 3.89$ & Alt & 19 & 15.8 \\
& & $3.89<\mathrm{X} \leq 4.99$ & Orta & 81 & 67.5 \\
& $4.99>\mathrm{X}>6$ & Üst & 20 & 16.7 \\
\hline \multicolumn{7}{c}{ Toplam } \\
\hline
\end{tabular}

Tablo 8 incelendiğinde alt düzeyde bulunan öğretmen adayı sayısının 19; orta düzeyde 81; üst düzeyde 20 olduğu görülmektedir. Elde edilen bulgular doğrultusunda öğretmen adaylarından alt ve orta kademede bulunan \%83'lük kısmın çevre okuryazarlık becerilerinin yeterli olmadığı söylenebilir.

Öğretmen adaylarının çevre okuryazarlık düzeylerine göre çevresel problemleri algılama düzeyleri ise Tablo 9'da verilmiştir.

Tablo 9.

Fen Bilgisi Öğretmeni Adaylarının Çevre Sorunlarına Yönelik Alg1 Düzeylerinin Çevre Okuryazarlık Düzeyine Göre Analizi

\begin{tabular}{|c|c|c|c|c|}
\hline \multicolumn{2}{|c|}{ Çevresel problemler } & \multirow{2}{*}{$\begin{array}{c}\begin{array}{c}\text { Düşük } \\
\text { düzey }\end{array} \\
\text { Resim } \\
\text { (f) }\end{array}$} & $\begin{array}{l}\text { Orta } \\
\text { düzey } \\
\text { Resim } \\
\text { (f) }\end{array}$ & \multirow{2}{*}{$\begin{array}{c}\begin{array}{c}\text { Yüksek } \\
\text { düzey }\end{array} \\
\text { Resim } \\
\text { (f) }\end{array}$} \\
\hline \multirow{9}{*}{ Hava kirliliği (Total) } & & & & \\
\hline & Fabrika dumanı & 3 & 14 & 3 \\
\hline & $\begin{array}{l}\text { Soba dumanı } \\
\text { (özellikle kömür) }\end{array}$ & 1 & 7 & \\
\hline & Egzoz dumanı & 2 & 11 & 2 \\
\hline & Sigara dumanı & 4 & 2 & \\
\hline & Çöp gazı & & & 2 \\
\hline & $\begin{array}{l}\text { Bilinçsiz yakıt } \\
\text { tüketimi }\end{array}$ & & & 1 \\
\hline & $\begin{array}{l}\text { Parfüm ve deodorant } \\
\text { Kullanımı }\end{array}$ & & & 3 \\
\hline & $\begin{array}{l}\text { Ozon tabakasının } \\
\text { İncelmesi }\end{array}$ & & 1 & 3 \\
\hline \multirow[t]{2}{*}{ Görsel kirlilik } & Çöplerin yere atılmas 1 & 8 & 44 & 3 \\
\hline & Fabrika binaları & & 5 & 5 \\
\hline
\end{tabular}




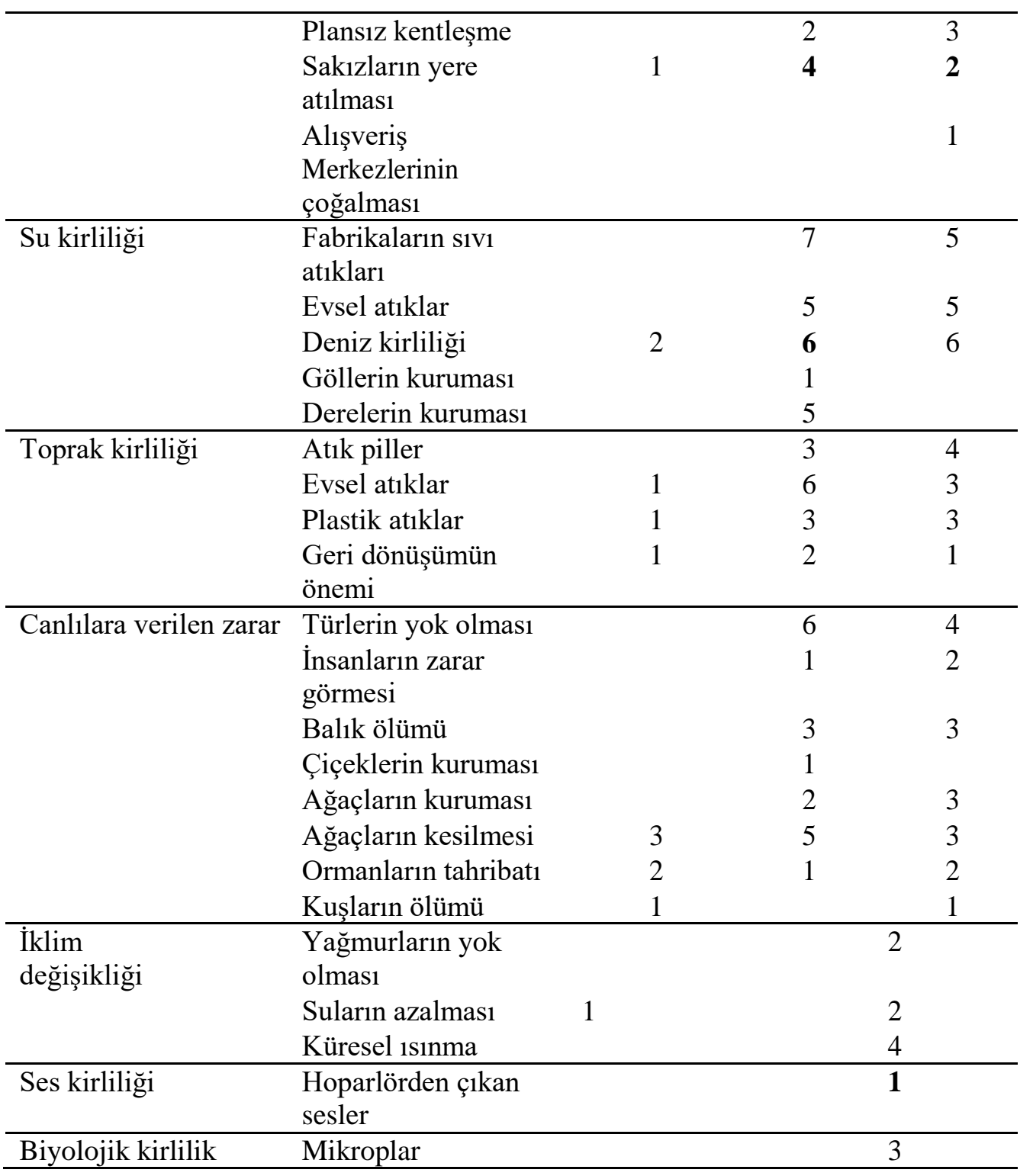

Tablo 9 incelendiğinde düşük düzeyde yer alan fen bilgisi öğretmeni adaylarının ağırlıklı olarak çöplerin yere atılmasından ve çevrelerinde içilen sigaradan çıkan dumanlardan etkilendikleri tespit edilmiştir. Orta düzeyde çevre okuryazarlık bilgisine sahip olan öğretmen adaylarının ise çöplerin yere atılmasından, fabrika ve egzoz dumanlarından etkilendikleri görülmüștür. Yüksek düzeyde çevre okuryazarlık becerisine sahip olan öğretmen adaylarının vermiş olduğu yanıtlar incelendiğinde ise; bu bireylerin en fazla evsel atıklardan, bunun sonucunda oluşan deniz kirliliğinden, deniz kirliliği sonunda oluşan türlerin yok olması durumundan, küresel ssınmadan ve atık pillerden etkilendikleri tespit edilmiştir.

\section{Tartışma, Sonuç ve Öneriler}

$\mathrm{Bu}$ çalışmada fen bilgisi öğretmeni adaylarının çevre okuryazarlık becerileri incelenerek çevre okuryazarlık becerilerinin çevre sorunlarına yönelik bakış açılarına olan etkisi incelenmiştir. Araştırma sonunda öncelikle ögretmen adaylarının bilgi alt boyutunda yeterli düzeye sahip olmadıkları tespit edilmiştir. Bu kapsamda öğretmen adaylarının en fazla Türkiye'deki akarsu ve deniz kirliliğinin en temel nedeni ile ilgili soruyu doğru olarak cevapladıkları, daha sonra biyo çeşitlilik ve türlerin azalması ile ilgili sorulara doğru yanıt verdikleri görülmüştür. Öğretmen adaylarının önemli karbon monoksit kaynağı olarak motorlu araçların yer aldığı 
soruya en az doğru yanıt verdikleri belirlenmiştir. Ayrıca çoğu öğretmen adayının nükleer atık depolama yöntemleri ile ilgili bilgilerinin olmadığı tespit edilmiştir. $\mathrm{Bu}$ bulgular öğretmen adaylarının çevre sorunlarına yönelik bilgi düzeylerinde yüzeysel bilgiye sahip olduklarını göstermektedir. Yani öğretmen adaylarının daha çok yakın çevrelerinde karşılaştıkları sorunlarla ilgilendikleri; çevre sorunu olup küresel anlamda problem yaratan sorunları çok fazla algılayamadıkları söylenebilir. Bu sonuçla ilgili olarak Hoban, Loughran ve Nielsen (2011) yapmış oldukları çalışmalarında, çevre ile ilgili konularda bireylerin öncelikle somut durumlara odaklandığ 1 ve bilişsel yapısını somut kavramlara yönelik oluşturduğunu ifade etmektedir. $\mathrm{Bu}$ sonuca göre bireyler öncelikle yakın çevrelerindeki olayları anlamlandırmakta, sonraki düzeylerde ise ilişksel yapıları anlamlandırabilmektedir (Roth, 1992). İlgili literatür incelendiğinde Türkiye'de yapılan çalışmalarda da günlük yaşantının çevre eğitimi üzerinde etkilerinin olduğunu belirten çalışmaların sonuçları, bu çalışmadan elde edilen sonucu destekler durumdadır (Artun ve Okur, 2015; Tekgöz, Şahin ve Ertepınar, 2010; Ünal ve Dımışkı, 1999; Yılmaz, Morgil, Aktuğ ve Göbekli, 2002). Oysaki çevre okuryazarlığının tanımları incelendiğinde tanımların bu becerinin gelişiminde öncelikle yeterli düzeyde bilginin olması gerektiğini vurguladıkları görülmektedir (NEETF, 2002). Dolayısıyla öğretmen adaylarının çevre okuryazarlık boyutunda öncelikle bilgi düzeylerinin yeterli düzeye ulaşmasının sağlanması çok önemlidir.

Araştırmada öğretmen adaylarının çevreye yönelik tutumları incelendiğinde; sonuçlar, öğretmen adaylarının \%50 oranında olumlu tutuma sahip olduklarını göstermektedir. Ancak öğretmen adaylarının hala insanın doğaya hükmetme hakkının olduğunu ve doğayı kendi çıkarı için kullanabileceğini de savundukları tespit edilmiştir. Bu bulgu öğretmen adaylarının ekoloji yanlısı bir görüşe sahip olmadıklarını göstermektedir. Ayrıca çevre okuryazarlığı kullanım alt boyutunda insan ve çevre ilişkisi ile ilgili öğretmen adaylarının yeterli farkındalığa sahip olmadıkları tespit edilmiştir. Özellikle "Zehirli yılanlar ve böcekler insanlar için tehdit oluşturdukları için öldürülmelidirler" gibi ifadelere yüksek düzeyde katıldıklarını göstermeleri insanı merkeze alan bir dünya görüşünü savunduklarını göstermektedir. Bu durumu Teksöz, Şahin ve Ertepınar (2010), doğanın insan için yaratılmış olduğuna inanan ve merkeze insanı alan bireylerin teknolojinin gelişmesiyle birlikte bütün çevre sorunlarının çözüleceğini savunduklarını; dolayısıyla üzerlerine düşen görevler konusunda sorumluluk almaya sicak bakmadıklarını ifade ederek özetlemişlerdir. Dillon ve Gayford (1997) çalışmalarında çevreye yönelik bilginin tutumu etkilediğini bilgi düzeyi arttıkça çevreye yönelik tutumun da pozitif yönde arttığını belirtmişlerdir. Tutumun artması da çevreye yönelik kullanım ve ilgide de artışı desteleyecektir. Yani, bireyler çevre ile ilgili bilgi kazanımlarına sahip olmadığı takdirde çevresindeki olayları anlayamayacağı için olay ve olgulara yönelik ilgi oluşturamamakta ve duyuşsal olarak çevreye yönelememektedirler. Duyuşsal olarak çevreyi anlayabilmeleri ve bu anlamda gelişebilmeleri için öncelikle bilişsel bilgi boyutunda belli bir alt yapılarının oluşması gereklidir. Dolayısıyla bu durumun nedeni olarak öğretmen adaylarının bilgi düzeylerinin yetersizliği gösterilebilir. Yine ilgi alt boyutu incelendiğinde öğretmen adaylarının içme suyu ve hava kirliliğine yoğunlaştıkları görülmüştür. Bu bulguya göre öğretmen adaylarının çevrelerinde gördükleri ve etkilendikleri problemleri ifade ettikleri yani, deneyim ve yaşantının ilgiyi etkilediği söylenebilir. Cheng ve Wu (2015) yapmış oldukları çalışmada da yine çevresel konular üzerinde yüksek düzeyde bilgi seviyesine sahip olan bireylerin çevreye yönelik ilgi düzeylerinin de yüksek düzeyde olduğunu tespit etmiş̧lerdir.

Araştırmada Öğretmen adaylarının çevre okuryazarlık düzeyine göre çevresel sorunları algılama durumları incelendiğinde düşük düzeydeki öğretmen adaylarının çevrelerindeki çöplerden rahatsız oldukları görülmüştür. Orta düzeydeki öğretmen adaylarının yine çöplerden ve fabrika, egzoz dumanlarından etkilendikleri yüksek düzeydekilerin ise evsel atıklardan, bunun sonucunda oluşan deniz kirliliğinden, deniz kirliliği sonunda oluşan türlerin yok olması durumundan, küresel 1sınmadan ve atık pillerden etkilendikleri tespit edilmiştir. Elde edilen bu sonuç öğretmen adaylarının çevre okuryazarlık düzeyi arttıkça çevrelerine daha bilinçli gözle baktığını ve olay ya da sorunları daha net gördüğünü ifade etmektedir. Dolayısıyla çevre okuryazarlık becerisinin artması çevresel olaylara yönelik algıyı etkilemektedir. Bu nedenle 
bütün bireylerin çevre okuryazarlık becerisi kazanmalarını sağlamak için öncelikle geleceğin öğretmenleri olarak, genç nesillerin de bu becerilere sahip olmaları desteklenmelidir. Dolayısıyla, yükseköğretimde çevre eğitimi ile ilgili hedeflerin belirlenmesi, öğretmen adaylarının bu hedeflere ulaşmaları için gerekli alt yapının hazırlanması ve sürecin olması gerektiği gibi işler olup olmadığının tespiti için bilimsel araştırmaların bu konuda destek sağlaması son derece önemlidir.

\section{Kaynaklar}

Altın, M., Bacanlı, H. ve Yıldız, K. (2002, Eylül). Biyoloji öğretmeni adaylarının çevreye yönelik tutumları. V. Ulusal Fen Bilimleri ve Matematik Ĕgitimi Kongresi, 16-18 Eylül 2002, Ankara, Türkiye.

Artun, H. ve Okur, M. (2015). Ortaokul öğrencilerinin çevre kavramına yönelik bilgi ve çevreyi anlama düzeylerinin belirlenmesi. Dicle Üniversitesi Ziya Gökalp Eğitim Fakültesi Dergisi, 24(2015), 277-293.

Bağc1 Kılıç, G. (2003). Üçüncü uluslararası matematik ve fen araştırması: fen öğretimi, bilimsel araştırma ve bilimin doğası. İlkögrretim Online, 2(1), 42-51.

Borthwick, A. (2011). Children's perceptions and attitudes towards their mathematics lessons. C. Smith, (Yay. haz.). British Society for Research into Learning Mathematics, 31, 37 42.

Cheng, T. M. ve Wu, H.C. (2015). How do environmental knowledge, environmental sensitivity, and place attachment affect environmentally responsible behavior? An integrated approach for sustainable island tourism. Journal of Sustainable Tourism, 23(4), 557-576.

Coyle, K. (2005). Environmental literacy in America: What ten years of neetf/roper research and related studies say about environmental literacy in the U.S. Washington, D.C: The National Environmental Education \& Training Foundation.

Creswell, J. W. (2012). Educational research: planning, conducting, and evaluating quantitative and qualitative research (4. bs.). Boston: Pearson.

Culen, G. R. (1998). The status of environmental education with respect to the goal of responsible citizenship behavior. Columbus: The Ohio State University.

Dillon, P. J. ve Gayford, C. G. (1997). A psychometric approach to investigating the environmental beliefs, intentions and behaviours of preservice teachers. Environmental Education Research, 3, 283-297.

Dinsinger, J. F. ve Roth, C. E. (1998). Environmental Literacy. ERIC/CSMEE Digest (Colombus, OH, ERIC Clearinghouse for Science, Mathematics and Environmental Education, ED 351201).

Ernst, J. (2009). Influences on U.S. middle school teachers' use of environment-based education. Environmental Education Research, 15(1), 71-92.

Erten, S. (2003). 5. sınıf öğrencilerinde "çöplerin azaltılması" bilincinin kazandırılmasına yönelik bir öğretim modeli. Hacettepe Üniversitesi Ĕ̈itim Fakültesi Dergisi, 25, 94103.

Farsakoğlu, O. F., Şahin, Ç., Karslı, F., Akpınar, M. ve Ültay, N. (2008). A study on awareness levels of prospective science teachers on science process skills in science education, World Applied Sciences Journal, 4(2), 174-182.

Hungerford, H. ve Simmons, B. (2003). Environmental educators a conversation with Paul Hart. Journal of Environmental Education, 11, 4-11.

Intergovernmental Panel On Climate Change (IPCC). (2014). Climate change 2014-impacts, adaptation and vulnerability. contribution of working group II to. The Fifth Assessment Report of The IPCC. Cambridge: Cambridge University.

Kaplowitz, M. D. ve Levine, R. (2005). How environmental knowledge measures up at a big ten university. Environmental Education Research, 11(2), 143-160.

Knapp, D. H. ve Barrie, E. (2001). Connect evaluation of an environmental science field trip. Journal of science Education and Technology, 10(4), 351-357. 
Knight, S. L., Nolan, J., Lloyd, G., Arbaugh, F., Edmondson, J. ve Whitney, A. (2013). Quality teacher education research: How do we know it when we see it? Journal of Teacher Education, 64(2), 114-116.

Köse, S. (2008). Diagnosing student misconceptions: using drawings as a research method. World Applied Sciences Journal, 3(2), 283-293.

Kurt, H., Gökmen, A. ve Ekici, G. (2014). Öğretmen adaylarının "bilgisayar" kavramı konusundaki bilişsel yapılarının belirlenmesi. Gazi Üniversitesi Gazi Eğitim Fakültesi Dergisi, 34(3), 357-401.

Liu, S. Y., Yeh, S. C., Liang, S. W., Fang, H. T. ve Tsai, H. M. (2015). A national investigation of teachers' environmental literacy as a reference for promoting environmental education in Taiwan. J. Environ. Educ, 46(2), 114-132.

Miles, M. B. ve Huberman, A. M. (1994). Qualitative data analysis: an expanded sourcebook (2nd ed.). Thousand Oaks, CA: Sage Publications.

Newell, R. ve Dale, A. (2015). Meeting the climate change challenge (MC3): The role of the internet in climate change research dissemination and knowledge mobilization. Environmental Communication, 9(2), 208-227.

Orr, D. (1992). Ecological literacy. Albany: State University of New York Press.

Orr, D. (1994). Earth in mind: on education, environment, and the human prospect. Washington, D.C.: Island Press.

Özer, U. (1991). Environmental philosophy within the relationships of humanity, environment, culture and economy. Man and the Environment Conference Proceedings, 1, 318-321.

Plevyak, L., Bendixen-Noe, M., Henderson, J., Roth, R. E. ve Wilke, R. (2001). Level of teacher preparation and implementation of ee: mandated and non-mandated ee teacher preparation states. Journal of Environmental Education, 28, 36-49.

Reiss, M. J. ve S. D. Tunnicliffe. (2001). Students' understandings of human organs and organ systems. Research in Science Education, 31(3), 383-399.

Rickinson, M. (2001). Learners and learning in environmental education: A critical review of the evidence. Environmental Education, 8(2), 120-139.

Robottom, I. ve Kyburz-Graber, R. (2000). Recent international developments in professional development in environmental education: Reflections and issues. Canadian Journal of Environmental Education, 5(1), 249-267.

Roth, C. E. (1992). Environmental literacy: its roots, evolution and directions in the 1990s. Columbus, OH: ERIC/SMEAC Information Reference Center.

Sauvé, L. (1996). Environmental education and sustainable development: a further appraisal. Canadian Journal of Environmental Education (CJEE), 1(1), 7-34.

Simmons, D. (2005). Educational reform, setting standards, and environmental education. H. R. Hungerford, W. J. Bluhm, T. L. Volk ve J. M. Ramsey (Yay. haz.). Essential readings in environmental education içinde (3rd ed., s. 65-72). Champaign: Stipes Publishing.

Smith, R. L. (1974). Thoughts on humans and their role in the environment. H. R. Hungerford. (Yay. haz.). Ecology: An introduction for non-science majors. Champaign: Stipes Publishing.

Sözer, E.(1991). Türk üniversitelerinde öğretmen yetiştirme sistemlerinin ögrretmenlik davranışları kazandırma yönünden etkililiği. Eskişehir: Anadolu Üniversitesi Basımevi.

Stapp, W. B. (1969). The concept of environmental education. H. R. Hungerford, W.J. Bluhm, T. L. Volk ve J. M. Ramsey (Yay. haz.). Essential readings in environmental education içinde (3rd ed., s. 33). Champaign, IL: Stipes Publishing.

Taştan Kırık, Ö.ve Kaya, H. (2014). 6. sınıf öğrencilerinin hücre konusundaki kavramsal yapıları hakkında nitel bir çalışma. International Online Journal of Educational Sciences, 6(3), 737-760.

Teksöz, G., Şahin, E. ve Ertepınar, H. (2010). Çevre okuryazarlığı, öğretmen adayları ve sürdürülebilir bir gelecek. Hacettepe Üniversitesi Ë̆itim Fakültesi Dergisi (H. U. Journal of Education) 39, 307-320. 
Fettahlığlu

The National Environmental Education \& Training Foundation (NEETF). (2002). Americans' low "Energy IQ:" A risk to our energy future; The tenth annual national report card: Energy knowledge, attitudes, and behavior. Washington, DC: Author.

Tien-Ming Cheng ve Homer C. Wu (2015) How do environmental knowledge, environmental sensitivity, and place attachment affect environmentally responsible behavior? An integrated approach for sustainable island tourism. Journal of Sustainable Tourism, 23(4), 557-576.

Ünal, S. ve Dımışkı, E. (1999). Unesco-Unep himayesinde çevre eğitiminin gelişimi ve türkiye'de ortaöğretim çevre eğitimi. Hacettepe Üniversitesi Eğitim Fakültesi Dergisi, 16(17), 142-154

Volk, T. L. ve W. McBeth. (1997). Environmental Literacy in the United States. H. R. Hungerford, W. J. Bluhm, T. L. Volk ve J. M. Ramsey (Yay. haz.). Essential readings in environmental education içinde (3rd ed., s. 73-86). Champaign: Stipes Publishing.

Whitehead, J. ve McNiff, J. (2004). Action Research Living Theory. London: Sage.

Yıldız,K., Sipahioğlu, Ş. ve Yılmaz, M. (2005). Çevre bilimi. Ankara: Gündüz Eğitim ve Yayınc1lik.

Yılmaz, A., Morgil, İ., Aktuğ, P. ve Göbekli, İ. (2002). Ortaöğretim ve üniversite öğrencilerinin çevre ve çevre kavramları ve sorunları konusundaki bilgileri ve önerileri, Hacettepe Üniversitesi Ĕ̈itim Fakültesi Dergisi, 22, 156-162.

Yin, Y., Mizokami, S. ve Aikawa, K. (2015). Compact development and energy consumption: scenario analysis of urban structures based on behavior simulation. Applied Energy, $159,449-457$.

\section{Extended Abstract}

\section{Introduction}

Today, environmental issues and environmental problems are increasing a little more with each passing day and causes negative effect on our World (Newell \& Dale, 2015; Yin, Mizokami \& Aikawa, 2015). In order to prevent these negative effects, it should be trained environmental literacy individuals (Altın, Bacanlı \& Yıldız, 2002; Orr, 1994; Özer, 1991). One of the most important factors for achieving the expected goals in environmental education is teachers (Bağc1 Kılıç, 2003; Sözer, 1991). In this regard, teachers must have certain skills. Teachers acquire knowledge and skills that they have for their job in faculties of education for their pre-service teacher training. One of these acquires is environmental literacy. In the literatüre, environmental literacy define as capacity to show the individual's environmental knowledge as behavior (Roth, 1992). According to Dinsinger and Roth (1992); an environmental literate individual must be an individual capable of using environmental behavior, beliefs, views and attitudes in the detection and prevention of environmental problems as well as having a broad environmental knowledge. So, it is very important to identify level of pre service teachers' environmental literacy and configure their education according to their level of environmental literacy in education faculty. In this context the purpose of this study is to analyses the feelings and thoughts of pre service science teachers regarding the problems they experience in their environment and to determine their suggestions for solving these problems with the help of the pictures they have drawn themselves by environmental literacy level.

\section{Method}

The research is held in 2013-2014 spring semester, at A state University, Faculty of Education, Elementary School Teaching Department, $1^{\text {st }}, 2^{\text {nd }}, 3^{\text {rd }}$ and $4^{\text {th }}$ year students -120 students in total. The data of the study were collected in accordance with qualitative research methods such as preservice science teacher' drawings and quantitative research methods such as environmental literacy questioners was developed by Kaplowitz and Levine (2005) and translated into Turkish by Teksöz, Şahin and Ertepınar (2010). Also in this study preservice science teachers explained that what they want to draw in their pictures by reponse open ended 
questions. Cartoons drawn by pre-service science teachers and pre service science teachers' responses to open-ended questions were analyzed using content analysis. The icons in the cartoons and the submissions with oral statements were categorized by coded. The findings obtained from the Environmental literacy scale were analyzed by using descriptive analyze method.

\section{Result and Discussion}

According to the pre-service science teachers who participate in this study, the most important environmental issues are water pollution, air pollution and noise pollution. At the end of this study it was found that pre-service science teachers's perspectives according to environmental problems has changed according to their environmental literacy levels. At the end of the research, it was determined that pre-service science teachers did not have sufficient level of knowledge sub-dimension. When the results of pre-service science teachers ' attitudes are examined, the results show that $50 \%$ of pre-service science teachers have a positive attitude. In addition, it was determined that pre-service science teachers did not have sufficient awareness related to human and environment relation for the sub-dimension of environmental literacy use. When the sub-dimension of interest was examined, it was seen that pre-service science teachers concentrated on drinking water and air pollution. Dillon and Gayford (1997) reported that environemnt knowledge influenced attitudes. According to them, as the level of knowledge increased, the attitude toward the environment also increased in the positive direction. The increase in attitude will also help to increase the usage and the interest in the environment. Therefore, the inadequacy of the knowledge level of pre-service science teachers can be shown as the reason for this situation. When examining the perception of environmental problems by pre-service science teachers according to level of environmental literacy, it was found that lowlevel science teachers were disturbed by the garbage around them. Also it was determined that middle-level pre-service science teachers were affected by garbage and factory, exhaust fumes. On the other hand, it was found that higher level pre-service science teachers were affected by domestic wastes, marine pollution caused by domestic wastes, reduction of species caused by marine pollution, global warming and waste pills. This result indicates that as the level of environmental literacy increases, pre-service science teachers take a more conscious look at their surroundings and see the events or problems more clearly. 